\title{
COVID-19 may transmit through aerosol
}

\author{
Juan Wang ${ }^{1} \cdot$ Guoqiang $\mathrm{Du}^{2}$
}

Received: 7 March 2020 / Accepted: 17 March 2020 / Published online: 24 March 2020

(C) Royal Academy of Medicine in Ireland 2020

Dear Editor,

On Feb 18, the National Health Commission of the People's Republic of China published the guidelines for the diagnosis and treatment of COVID-19 infection (trial version 6) [1]. With the awareness and understanding of the disease, the guidelines show that the droplets and close contact transmission are the main routes of transmission, and aerosol transmission is possible under the condition of long exposure to high concentrations of aerosols in a relatively closed environment [1].

Aerosols are particles formed by solid or liquid particles dispersed and suspended in the air. They contain soil particles, industrial dust particles, particulates emitted by automobiles, bacteria, microorganisms, plant spore powders, and other components. When a person, who was infected with the virus, coughs, sneezes, breathes vigorously, or speaks loudly, the virus will be excreted from the body and may dissolve with the aerosol and become the bio-aerosols. The particles in a bio-aerosol are generally 0.3 to $100 \mu \mathrm{m}$ in diameter; however, the respirable size fraction of 1 to $10 \mu \mathrm{m}$ is of primary concern. Bio-aerosols ranging in size from 1.0 to $5.0 \mu \mathrm{m}$ generally remain in the air, whereas larger particles are deposited on surfaces. Droplets are droplets of saliva discharged by people sneezing or coughing, and their particle size is generally 1 to $5 \mathrm{~mm}$. They spread in a space of about 1 to $2 \mathrm{~m}$ from the source of infection. However, the aerosol can travel hundreds of meters or more. More importantly, current researches have proven that aerosols are involved in the spread of SARS, MERS, H1N1, and some other diseases [2-5].

If COVID-19 infection cannot transmit by aerosol, it will hardly to explain some confirmed cases. On Feb 3, the Disease Control Department of Dalat Banner, Ordos City, Inner

Guoqiang Du

15002497163@163.com

1 Department of Clinical Laboratory, the Affiliated Hospital of Qingdao University, Qingdao, Shandong, China

2 Department of Otolaryngology Head and Neck Surgery, Qingdao Municipal Hospital (Group), No.5 Donghai Middle Road, Qingdao 266071, Shandong, China
Mongolia, announced that the fourth confirmed case lived upstairs of the first confirmed case, who went up and down the building several times by passing by the door of the first confirmed case, of whom the door was often opened and there was some domestic garbage beside the door [6]. Moreover, four clinical laboratory technicians in the Department of Clinical Laboratory of Jinyintan Hospital, Wuhan, were infected with COVID-19, of whom had no contact with the confirmed cases [7]. How did they get infected? One possibility is that the patients' blood samples are exposed to the air to form aerosols, and the viruses in the aerosols are transmitted to the four technicians. All in all, COVID-19 may transmit through aerosol directly, but it needs to be further verified by experiments. If the aerosols can spread COVID-19, prevention and control will be much more difficult.

Authors' contributions JW and GD wrote the initial draft of the manuscript. GD conceived the manuscript. All authors critically reviewed the manuscript and approved the final version of the manuscript.

\section{Compliance with ethical standards}

Conflict of interest The authors declare that they have no conflict of interest.

Ethics approval This article does not contain any studies with human participants or animals performed by any of the authors.

Consent to participate Not applicable.

Consent for publication All authors approved the publication of the manuscript.

Availability of data and material Not applicable.

Code availability Not applicable. 


\section{References}

1. The National Health Commission of the People's Republic of China. http://www.nhc.gov.cn/xcs/zhengcwj/202002/8334a8326dd94d329 df351d7da8aefc2.shtml

2. Yu IT, Li Y, Wong TW, Tam W, Chan AT, Lee JH, Leung DY, Ho T (2004) Evidence of airborne transmission of the severe acute respiratory syndrome virus. $\mathrm{N}$ Engl J Med 350:1731-1739. https://oi. org/10.1056/NEJMoa032867

3. Adhikari U, Chabrelie A, Weir M, Boehnke K, McKenzie E, Ikner L, Wang M, Wang Q, Young K, Haas CN, Rose J, Mitchell J (2019) A case study evaluating the risk of infection from middle eastern respiratory syndrome coronavirus (MERS-CoV) in a hospital setting through bioaerosols. Risk Anal 39:2608-2624. https://doi.org/10. 1111/risa.13389

4. Zhang H, Li X, Ma R, Li X, Zhou Y, Dong H, Li X, Li Q, Zhang M, Liu Z, Wei B, Cui M, Wang H, Gao J, Yang H, Hou P, Miao Z, Chai
$\mathrm{T}$ (2013) Airborne spread and infection of a novel swine-origin influenza a (H1N1) virus. Virol J 10:204. https://doi.org/10.1186/ 1743-422X-10-204

5. Kulkarni H, Smith CM, Lee Ddo H, Hirst RA, Easton AJ, O'Callaghan C (2016) Evidence of respiratory syncytial virus spread by aerosol. Time to revisit infection control strategies? Am J Respir Crit Care Med 194:308-316. https://doi.org/10.1164/rccm.201509$18330 \mathrm{OC}$

6. China. org.cn, http://news.china.com.cn/2020-02/04/content 75670739.htm

7. I guard the intensive care unit in jinjintan, wuhan, https://news.sina. com.cn/s/2020-01-30/doc-iimxxste7697789.shtml

Publisher's note Springer Nature remains neutral with regard to jurisdictional claims in published maps and institutional affiliations. 